\title{
COMPARISON OF MERCHANT-ARTISAN FROM TRADE AND TAX LAW
}

\author{
Muhammet DURDU ${ }^{1}$
}

\author{
Ümit Süleyman ÜSTÜN²
}

\begin{abstract}
Real person revenues occurs; coomercial gains, agricultural gains, fees, self employment, real estate properties, movable rentals and other earnings and revenues. The distinction between the merchant and the artisan is considered as a distinction made within the component of the commercial gain. This distinction, as a rule, quantitative limit is put; large-volume traders are named merchant, the others are called artisan. The distinction between merchants and artisans is noteworthy as the distinction to which many important rulings are attached to the conclusions of tax and commercial law. In general, it is observed that, while more responsibility is imposed on merchants, artisans are more likely to seek protection. In the study, trade law and tax law will be compared in terms of merchant-artisan discrimination and it will be investigated whether the discrimination made has caused fair outcomes. The concept of artisan is more broadly regulated in commercial law. It would not be correct to say that the narrowing of the artisan concept in the tax law brings too much burden to the commercial earners in terms of their material and formal assignments. Because, in the tax law, differences are created between the people who are accepted as taxpayers, and they have more tasks for large-volume commercial gains and less material and formal tasks for small-volume commercial gains.
\end{abstract}

Keywords: Merchant, artisan, simple procedural gains, real person revenues

JEL Code: K34, K22.

\section{Introduction}

In the provision 2 of the Income Tax Law no. 193, the earnings elements of real persons were determined. Accordingly, the elements of real person income; commercial gains, fringe benefits, fees, self-employment profits, real estate capital gains, movable capital gains and other gains and revenues. The distinction between the merchant and the artisan is considered as a distinction made within the component of the commercial gain.

The distinction between merchant and artisan attracts attention as the distinction that many important judgments attach to the results of tax and commercial law. In general, it is observed that, while more responsibility is imposed on merchants, artisan are more likely to be protected.

In the study, first of all, the tax law will examine the distinction between merchants and artisans, and then the basic principles of the distinction between merchants and artisans will be examined in terms of commercial law. In the conclusion section, trade law and tax law will be compared in terms of merchant-trader discrimination and it will be investigated whether the discrimination made has caused fair outcomes.

\footnotetext{
1 Res. Asst., Necmettin Erbakan University, Faculty of Law, Division of Fiscal Law, mdurdu@erbakan.edu.tr

2 Prof. Dr., Selçuk University, Law of Faculty, Division of Fiscal Law, sustun@selcuk.edu.tr
} 


\section{Merchant-Artisan Differentiation in Terms of Tax Law}

According to the relevant provisions of the Income Tax Law No. 193, commercial income holders are subject to taxation; can not be taxable artisans and taxable commercial gains. The taxpayers, according to the taxation procedures, are divided into real and simple procedures. Real procedures are divided into balance sheet basis ( $1^{\text {st }}$ class merchants) and business account basis ( $2^{\text {nd }}$ class merchants) (Gümüş, 2013: 76).

\subsection{The Concept of Merchant in Tax Law}

In tax law, differences are created between taxpayers according to large-volume workers and for small-volume workers, resulting in less material and formal tasks. For example, in terms of bookkeeping obligation, in the tax law, It is seen that First class merchant are given three different bookkeeping assignments, namely journal, bookkeeping and inventory book. Second class traders have only the obligation to keep business accounts. The merchants subject to the simple procedure do not have any bookkeeping obligations. The profits of these persons are determined and taxed through documents such as vouchers, invoices and receipts they are obliged to exchange and by means of declarations they will give. In terms of material duties, differences were made between the traders according to their size, by differentiating the tax rates and by exemptions. In this way, small volume commercial income is aimed at saving the burden of counting merchants.

\subsection{The Concept of Artisans in Tax Law}

In provision 9 of the Income Tax Law No. 193, income tax exempt trades were regulated. Counts of trades exempted from income tax on the subject matter have been determined in a proper manner. The extract is considered to be an exempted tradesman who is a small, mobile or at home worker without being bound to a work place. It is stated that the exemption of trades is an application of the principle of fair distribution of the tax burden within the context of the social purpose of the taxation of the state from the constitutional aims of the state (Biniş, 2015: 54).

There is no consensus as to whether the commercial traders who are subject to simple procedure will be expressed by the concept of merchant or artisan.In legal regulations, the concept of merchant is used for these individuals, but they are accepted as artisan in doctrin and judicial decisions.

\section{Merchant-Artisan Separation in Terms of Commercial Law}

The distinction between merchants and artisans in commercial law is important for determining who will be subject to the provisions and consequences of being a merchant by means of this distinction. In commercial law, it is observed that the distinction between merchan and artisan is basically made with quantitative criteria.

\subsection{The Concept of Merchant in Commercial Law}

In commercial law, merchants are divided into real person merchants, legal person merchants and equipments (Dinç, 2015: 118). The actual person who is mainly interested in the work is the merchants. It is not possible for legal entities to be regarded as an artisan. For this reason they can not deal with merchant-artisan. 


\subsection{The Concept of Artisan in Commercial Law}

It deals with the concept of trades in commercial law; There are basic regulations in the Turkish Commercial Code numbered 6102, Law No. 5362 on Tradesmen and Tradesmen Organizations and Decree No. 2007/12362 of the Council of Ministers. According to these arrangements, Law No. 6102, unlike the others, did not subject trades to being bound to a certain profession group. There is a serious contradiction in commercial law in this regard. The elimination of this dilemma is essential for the determination of the content of the trades concept in terms of commercial law.

\section{Conclusion}

In trade law and tax law, the distinction between merchant and artisan is connected to important results. As a matter of fact, the fact that a person is a merchant or artisan affects both the commercial and taxation provisions.

In trade and tax law, artisans are not subject to the provisions and consequences of being a merchant. Because, as mentioned above, being a merchant carries personal responsibility. By not carrying these responsibilities, artisans, who are accepted as having a small volume of commercial income are trying to provide justice by not carrying these responsibilities.

A person who is deemed to be an artisan in the commercial law and is wanted to be saved from the consequences, can be taxed as a merchant in tax law. In another expression, the distinction between commercial law and tax law differs from merchant-artisan. The concept of artisan is more broadly regulated in commercial law. It would not be correct to say that the narrowing of the artisan concept in the tax law brings too much burden to the commercial earners in terms of their material and formal assignments. Because, in the tax law, differences are created between the people who are accepted as taxpayers, and they have more tasks for large-volume employees and less material and formal tasks for small-volume employees.

\section{References}

Abdioğlu, H., Demirkapı, E. \& Erdöl, M. (2014). “Yeni Türk Ticaret Kanunu ve Vergi Usul Kanunu’na Göre Defterlerin İncelenmesi", Yönetim ve Ekonomi Dergisi, C. 21, S. 1, ss. 91-105.

Abdioğlu, H., Yumuşak, S. \& Uyar, E. (2014). “Vergi Usul Kanunu ve Türkiye Muhasebe Standartlarına Göre Amortisman Konusunun İncelenmesi ve Örnek Uygulamalar", Yönetim ve Ekonomi Araştırmaları Dergisi, S. 23, ss. 64-397.

Arslan, M. \& Biniş, M. (2012). "Türk Vergi Sisteminde Basit Usulde Vergilemenin Etkinliği”, Mali Çözüm Dergisi, S. 112, Temmuz-Ağustos, ss. 53-71.

Artar, Y. “6322 Sayılı Kanun Hükümlerinde Yer Alan Değişiklikler Sonrası Basit Usulde Vergilendirilme”, http://www.muhasebenet.net/haber.php?haber_id=3206, (06.11.2016).

Bakmaz, Z. (2010). "Türk Vergi Hukukunda Defter Tutma Yükümlülüğü", (Yüksek Lisans Tezi), Dokuz Eylül Üniversitesi Sosyal Bilimler Enstitüsü, İzmir. 
Battal, A. (2003). “Gerçek Kişilerin Tacir Sıfatına Sahip Olma ve Ifflasa Tabi Tutulma Şartları Konusundaki Yargıtay Uygulaması", Bthae XIX. Ticaret Hukuku ve Yargıtay Kararları Sempozyumu, Ankara.

Bay, H. (2003). “Gelir Vergisinde Basit Usul Uygulaması”, (Yüksek Lisans Tezi), Dokuz Eylül Üniversitesi Sosyal Bilimler Enstitüsü, İzmir.

Bayraklı, H. H. (1999). "Ticari Kazancın Basit Usulde Tesbiti ve Vergileme Süreci", Afyon Kocatepe Üniversitesi Sosyal Bilimler Dergisi, C. 1, S. 1, ss. 99-121.

Bilici, N. (2014). Türk Vergi Sistemi, 33. Baskı, Ankara.

Biniş, M. (2015). “Vergi Adaletini Sağlamaya Yönelik Bir Araç; Esnaf Muaflı̆̆ı", Kastamonu Üniversitesi iktisadi ve Idari Bilimler Fakültesi Dergisi, S. 7, Nisan, ss. 52-63.

Bloomberg HT, (09.02.2016), "Vergi Mükellefleri Artyyor", http://www.bloomberght.com/ haberler/haber/1853497-vergi-mukellefleri-artiyor, (10.11.2016).

Bozkurt, T. (2012). Ticari Işletme Hukuku, 7.Baskı, İstanbul.

Danıştay 3. Daire, 28.11.2012 Gün ve E. 2010/2303, K. 2012/3985, http://emsal.danistay. gov.tr/veribankasiıstemciweb/gelismisdokumanaraservlet?dokumanturleristring= danıstaykarar, \&aranan=esnaf\&aramag=sdsorrxp\&baslangic $=60 \&$ son $=80 \&$ dokumanturuadi=danıstaykarar \& fromsonucsayfasindan= true\&sonucsayfasi=yenitasarim/ aramasonuc.jsp\&sirala=3\& mevzuatadi=\&mevzuatno=\&mevzuatmadde=, (20.11.2016).

Danıştay 4. Daire, 02.05.2000 Gün ve E. 200/457, K. 200/1847, http://emsal.danistay.gov. tr/veribankasiıstemciweb/ gelismisdokumanaraservlet?dokumanturleristring= danıstaykarar, \&aranan=t\%c3\%bcccar \&aramag=sdsorrxp\&baslangic $=20 \&$ son= 40\&dokumanturuadi=danıstaykarar \&fomsonucsayfasindan=true\&sonucsayfasi= yenitasarim/aramasonuc.jsp \&sirala $=3 \&$ mevzuatadi $=\&$ mevzuatno $=\&$ mevzuatmadde $=$, (28.01.2017).

Danıştay 7. Daire, 12.05.2004 Gün ve E. 2001/4254, K. 2004/1238, http://emsal.danistay. gov.tr/veribankasiıstemciweb/gelismisdokumanaraservlet?dokumanturleristring= danıstaykarar, \&aranan=tacir \&aramag=sdsorrxp\&baslangic $=20 \&$ son $=40 \&$ dokumanturuadi=danıstaykarar\&fromsonucsayfasindan= true\&sonucsayfasi=yenitasarim/ aramasonuc.jsp\&sirala=3\&mevzuatadi= \&mevzuatno=\&mevzuatmadde=, (20.11.2016).

Danıştay 15. Daire, 16.11.2015 Gün ve E. 2015/1507, K. 2015/7590, http://emsal.danistay.gov. tr/veribankasilstemciweb/gelismisdokumanaraservlet, (20.11.2016).

Danıştay Iç̧tihadı Birleştirme Kurulu Kararı, 16.06.1994 Gün ve E. 1992/2, K. 1994/2. http://emsal. danistay.gov.tr/veribankasiıstemciweb/gelismisdokumanaraservlet?dokumanturleristring= danıstaykarar, \&aranan=\&aramag=sdsorrxp\&baslangic=20\&son=40\&dokumanturuadi= danıstaykarar\&fromsonucsayfasindan=true \&sonucsayfasi=yenitasarim/aramasonuc. jsp\&sirala=3\&mevzuatadi=\&mevzuatno=\&mevzuatmadde=, (28.01.2017).

Danıştay Vergi Dava Daireleri Genel Kurulu, 13.03.1992 Gün ve E. 1991/129, K. 1992/114, http://emsal.danistay.gov.tr/veribankasiıstemciweb/gelismisdokuman araservlet?dokumanturleristring=danıstaykarar,\&aranan=tacir\&aramag=sdsorrxp\& 
baslangic $=80 \&$ son $=100 \&$ dokumanturuadi $=$ danıstaykarar $\&$ fromsonuc sayfasindan $=$ true \&sonucsayfasi=yenitasarim/aramasonucjsp \&sirala=3\&mevzuatadi $=\&$ mevzuatno $=\&$ mevzuatmadde $=,(20.11 .2016)$.

Danıştay Vergi Dava Daireleri Genel Kurulu, E. 2005/110, K. 2005/117. http://www.kararara. com/danistay/vdd/danistay7908.htm, (28.01.2017).

Dedeağaç, E. (2012). 6102 Sayılı Türk Ticaret Kanunu'nun 1. Kitabına Iliş̧kin Görüşlerim, Ankara.

Demirkapı, E. (2012). "Ticari İşletmenin Tespiti Açısından Esnaf İşletmesi Kavramının Değerlendirilmesi", Gazi Üniversitesi Hukuk Fakültesi Dergisi, C. 17, S. 1-2, Ocak-Nisan, ss. 371-441.

Dinç, S. (2015). “6102 Sayılı Türk Ticaret Kanunu'na Göre Tacir Kavramı”, Türkiye Adalet Akademisi Dergisi, S. 23, Ekim, ss. 117-133.

Gelir İdaresi Başkanlığı (GiB). (2016). Ticari Kazancın Gerçek Usulde Vergilendirilmesi Rehberi, Şubat.

Gençyürek, L. "Basit Usulde Vergileme ve Ortaya Çıkan Olumsuz Tablo", http://www.alomaliye. com/2005/09/12/basit-usulde-vergileme-ve-ortaya-cikan-olumsuz-tablo/, (06.11.2016).

Gümüş, E. (2013). "Basit Usulde Vergilendirmenin Değerlendirilmesi”, Vergi Dünyası Dergisi, S. 378, Şubat, ss. 75-83.

Kılıç, C. (1999). "Basit Usulde Vergilendirme, Karşılaşılabilecek Sorunlar ve Çözüm Önerileri", Vergi Dünyası Dergisi, S. 210, Şubat, ss. 99-103.

Organ, I. \& Güler, A. (2012). "Şehir İçi Ulaşım Faaliyetlerinde Kazancın Basit Usulde Vergilendirilmesinin Yarattğı Vergi Adaletsizliği: Denizli Örneği”, Maliye Dergisi, S. 163, Temmuz-Aralık, ss. 187-203.

Topçu, F. (12.11.2015). "Basit Usulde Vergilendirme Kaldırılmalıdır", http://www.iktisadidayanisma. com/basit-usulde-vergilendirme-kaldirilmalidir/ haber/6e46d576-5450-489f-95847cba22ce6024.aspx, (06.11.2016).

Turgay, R. (1956). “Gelir Vergisinde Esnaf Muaflığının Genel ve Özel Şartları”, Maliye Araştırma Merkezi Konferansları 2, S. 13-3. 